\title{
Methotrexate Induced Accelerated Rheumatoid Nodulosis
}

\author{
Austin Cusick ${ }^{1}$, Amandeep Goyal ${ }^{2}$, Shehla Yasin Belgam Syed ${ }^{3}$ and Pankaj Bansal ${ }^{4 *}$ \\ ${ }^{1}$ Ohio University Heritage College of Osteopathic Medicine, USA
}

${ }^{2}$ Marietta Memorial Hospital, USA

${ }^{3}$ Boston University, USA

${ }^{4}$ Mayo Clinic Health System, USA

*Corresponding author: Pankaj Bansal, Mayo Clinic Health System, USA

\section{ARTICLE INFO}

Received: April 16, 2020

Published: 幽 April 23, 2020

Citation: Austin C, Amandeep G, Shehla Yasin Belgam S, Pankaj Bansal. Methotrexate Induced Accelerated Rheumatoid Nodulosis. Biomed J Sci \& Tech Res 27(2)-2020. BJSTR. MS.ID.004470.

Abbreviations: RA: Rheumatoid Arthritis; DMARD: Disease-Modifying Antirheumatic Drugs; MTX: Methotrexate; MIARN: Methotrexate-Induced Accelerated Rheumatoid Nodulosis; AICAR: 5-Aminoimidazole-4-Carboxamide-Ribonucleotide

ABSTRACT

Rheumatoid arthritis is common systemic autoimmune disease prevalent in European and American populations with a female predominance. Recent analysis of disease epidemiology suggests lifetime risk of $3.6 \%$ and $1.7 \%$ in females and males respectively. Methotrexate is a commonly used disease-modifying antirheumatic drug in the treatment of rheumatoid arthritis. A possible adverse effect of methotrexate therapy is the development of methotrexate induced accelerated rheumatoid nodulosis. We present the case of a 54-year-old female with seropositive rheumatoid arthritis who developed methotrexate induced accelerated rheumatoid nodulosis one year after initiating methotrexate therapy. Disease-modifying therapy was changed with subsequent cessation of further nodule development. The mechanism is likely secondary to methotrexate inducing adenosine accumulation and adenosine 1 receptor activation. The rarity of this manifestation suggests certain population susceptibility through retention of the HLA-DRB1*0401 allele. The rheumatoid nodule and the methotrexate induced nodule are difficult to distinguish through histopathology. Currently, treatment research is limited and often medication change is recommended with other disease-modifying medications to treat Rheumatoid Arthritis.
\end{abstract}

Keywords: Rheumatoid Nodulosis; Rheumatoid Arthritis; Methotrexate

\section{Introduction}

Rheumatoid arthritis (RA) is a common systemic autoimmune disease prevalent in European and American populations with female predominance. Recent analysis of disease epidemiology suggests lifetime risk of $3.6 \%$ and $1.7 \%$ in females and males respectively [1]. Overall, North American and Northern European populations have an incidence of $1 \%$ [2]. While the characteristic feature of RA is polyarticular erosive inflammatory arthritis, it is associated with several extra-articular and systemic manifestations. The most common cutaneous manifestation of RA is rheumatoid nodules, which have been reported in upto $35 \%$ of patients [3] and can be present at the initial presentation [4]. Several DiseaseModifying Antirheumatic Drugs (DMARDs) are currently available and approved for management of RA, with extensive evidence supporting prevention of radiographic progression of RA by early initiation of DMARD therapy [5]. Methotrexate (MTX) is considered the first-line conventional DMARD in the treatment of RA and is used as monotherapy as well as combination therapy. MTX is usually well tolerated; however, several adverse effects are often described with MTX therapy with reports describing up to $20 \%$ of patients discontinuing MTX secondary to adverse effects6. Amongst other adverse effects, several cutaneous manifestations have been reported in the literature [6,7]. A well described cutaneous manifestation includes induction of nodulosis after MTX administrationcalled Methotrexate-Induced Accelerated Rheumatoid Nodulosis (MIARN). MIARN is a rare dermatologic manifestation [8] and warrants investigation of the literature for understanding, pathophysiology, treatments, and described prognosis. 


\section{Case Presentation}

We present the case of a 54-year-old female who was diagnosed with seropositive (rheumatoid factor and anti-cyclic citrullinated peptide positive) RA three years ago. She was initially treated with corticosteroids and MTX. Corticosteroids were tapered off within one month of diagnosis. She was then maintained on MTX $25 \mathrm{mg}$ weekly resulting in low RA disease activity. One year after starting the MTX, the patient started developing nodules on her hands. These nodules were soft, non-tender and present on the palmar and dorsal aspect of bilateral hands on the proximal and distal interphalangeal joints. Due to concerns of MIARN, her MTX was discontinued, and she was started on leflunomide. Unfortunately, leflunomide therapy could not be tolerated secondary to gastrointestinal adverse effects. She was then started on certolizumab pegol. Re-evaluation in the clinic 6 months after discontinuation of methotrexate and initiation of certolizumab pegol assured that her RA still had low disease activity. The nodules on her hands diminished in size but did not completely disappear. The patient did report that new nodules no longer developed after medication change.

\section{Discussion}

MTX-induced accelerated nodulosis is a phenomenon in RA patients that is rare but described in the literature. Rare individual cases of MTX-induced nodulosis have been reported in other diseases including psoriatic arthritis [9] and juvenile idiopathic arthritis $[10,11]$ although most of the existing literature is in patients with RA. Current evidence suggests that certain individuals with RA are predisposed to developing this manifestation. Patients carrying certain alleles of HLA-DRB1 directly linked them to increased risk of MIARN. More specifically,the HLA-DRB1*0401 allele has been associated a significantly higher risk of accelerated nodulosis [12] with up to $71 \%$ of patients with MIARN carrying this allele which was seen in only $17 \%$ to $18 \%$ of control RA patients and healthy populations.

The pathophysiology of MIARN is multi-factorial which can attribute to the overall rarity of this manifestation. Inhibition of dihydrofolate reductase and thymidylate synthase leading to depletion of necessary precursors for nucleotide synthesis is a well-known mechanism of action of MTX, however, this action is thought to be responsible primarily for the anti-cancer properties of MTX [6]. Anti-inflammatory effects of MTX are primarily a result of inhibition of 5-aminoimidazole-4-carboxamide-ribonucleotide (AICAR) transformylase [13] leading to increased levels of AICAR. This subsequently inhibits Adenosine Monophosphate (AMP) deaminase, leading to an increase in levels of intracellular/ extracellular adenosine and AMP [14]. Adenosine binds to the Adenosine A2a receptors on lymphocytes, monocytes, macrophages, natural killer cells, and neutrophils leading to dampening of inflammation by several downstream mechanisms [15]. Thus, the buildup of adenosine stimulates A2 receptors stimulating anti-inflammatory effects of MTX. Paradoxically, stimulation of A1receptors on monocytes may induce giant cell formation and subsequently nodulosis [16]. Furthermore, there are stark differences in the gene expression in nodule tissue against synovial tissue of RA patients. Genetic components of methylation reactions downstream from dihydrofolate reductase tend to be reduced in nodule tissue in comparison to the synovium. This may be partially responsible for the different reactions of MTX therapy causing therapeutic benefit for RA and co-concomitant accelerated nodulosis [17]. Of note, immunosuppression has been directly linked to nodulosis in several settings. Epstein-Barr virus (EBV) infection in a patient with prior history of RA treated with MTX has been directly implicated in further nodule development [18]. The combination of MTX-induced immunosuppression with additional EBV infection is suspect for inducing nodule formation. This became evident by characteristics of typical rheumatoid nodules with lymphocyte proliferation and EBV detection on histology [18]. In addition, TNF-alpha inhibitors have been associated with accelerated rheumatoid nodulosis [19-21]; however, the mechanism describing this phenomenon is not clear and may be different from MTX's supposed role [16]. The summation of the literature up to this point is ultimately conflicting, but it is certain that immunologic modification in a genetically susceptible population is the priming agent for MIARN.

Clinically and histopathologically, MIARN can be difficult to differentiate from rheumatoid nodules. Observational data suggests a high percentage of patients who develop MIARN are positive for rheumatoid factor [12,22], which is also the case with rheumatoid nodules [23]. Development of MIARN does not necessarily depend on the cumulative dose or duration of MTX therapy, with reports of MIARN development after exposure to MTX ranging from 3 months [24-26] to 144 months [27] and after a cumulative dose ranging from $60 \mathrm{mg} 26$ to $7200 \mathrm{mg}$ [27]. MTX-induced nodules are smaller in comparison to rheumatoid nodules 8 and tend to be present predominantly on the fingers [22]. Like rheumatoid nodules, they are usually non-tender and soft. Histopathologically, these nodules are indistinguishable from rheumatoid nodules, both showing palisading granuloma formation evident by central necrosis and surrounding granulation tissue. The central necrosis is the result of necrotic macrophages and endothelial cells and is surrounded by palisading macrophages and granulation tissue consisting of histiocytes and lymphocytes. Focal vasculitis can be a feature in more than $30 \%$ of rheumatoid nodules [28] but is usually not seen in MTX-induced nodules [29]. The cause is often difficult to prove due to the stark similarities between rheumatoid nodules and MIARN in patients with RA, and it is assessed primarily based on time-course of events.

Currently, there is no evidence of any therapeutic strategy effective for the management of MIARN. Common practice is the discontinuation of the offending agent, typically MTX, or the antiTNF agent [30].Other medications with suggested effectiveness include hydroxychloroquine [31,32], colchicines [33,34], 
sulfasalazine [35] and D-penicillamine [26]; however, the research is limited and dated [30]. Further, it is unclear if the regression in nodules is secondary to discontinuation of MTX, or the new therapy. Possible protective effects of hydroxychloroquine when co-administered with MTX in future development of nodules has also been proposed [12]. Surgical excision is rarely indicated and not usually recommended due to increased risk of post-surgical complications including infection and delayed healing. Ultimately, due to the paucity of treatment guidelines, further investigation of MIARN pathophysiology and randomized control trials of potential targets will help isolate appropriate therapeutics or interventions needed for the future.

\section{Conflicts of Interest}

The authors have no conflicts or interests to declare.

\section{References}

1. Crowson CS, Matteson EL, Myasoedova E, Michet CJ, Ernste FC, et al. (2011) The lifetime risk of adult-onset rheumatoid arthritis and other inflammatory autoimmune rheumatic diseases. Arthritis Rheum 63(3): 633-699.

2. Silman AJ, Pearson JE (2002) Epidemiology and genetics of rheumatoid arthritis. Arthritis Res 4 Suppl 3: S265-S272.

3. Cojocaru M, Cojocaru IM, Silosi I, Vrabie CD, Tanasescu R (2010) Extraarticular manifestations in rheumatoid arthritis. Maedica (Buchar) 5(4) 286-291.

4. Nyhäll-Wåhlin BM, Turesson C, Jacobsson LT, Nilsson JÅ, Forslind K, et al. (2011) The presence of rheumatoid nodules at early rheumatoid arthritis diagnosis is a sign of extra-articular disease and predicts radiographic progression of joint destruction over 5 years. Scand J Rheumatol 40(2): 81-87.

5. Molina E, Del Rincon I, Restrepo JF, Battafarano DF, Escalante A (2015) Association of socioeconomic status with treatment delays, disease activity, joint damage, and disability in rheumatoid arthritis. Arthritis Care Res (Hoboken) 67(7): 940-946.

6. Wang W, Zhou H, Liu L (2018) Side effects of methotrexate therapy for rheumatoid arthritis: A systematic review. Eur J Med Chem 158: 502 516.

7. Enginar AÜ, Nur H, Gilgil E, Kaçar C (2019) Accelerated Nodulosis in a Patient With Rheumatoid Arthritis. Arch Rheumatol 34(2): 225-228.

8. Takashima S, Ota M (2015) Methotrexate-induced nodulosis. CMAJ 187(10): E327.

9. Berris B, Houpt JB, Tenenbaum J (1995) Accelerated nodulosis in a patient with psoriasis and arthritis during treatment with methotrexate. J Rheumatol 22: 2359-2360.

10. Falcini F, Taccetti G, Ermini M, Trapani S, Calzolari A, et al. (1997) Methotrexate-associated appearance and rapid progression of rheumatoid nodules in systemic-onset juvenile rheumatoid arthritis Arthritis Rheum 40: 175-178.

11. Muzaffer MA, Schneider R, Cameron BJ, Silverman ED, Laxer RM (1996) Accelerated nodulosis during methotrexate therapy for juvenile rheumatoid arthritis. J Pediatr 128: 698-700.

12. Ahmed SS, Arnett FC, Smith CA, Ahn C, Reveille JD (2001) The HLADRB1*0401 allele and the development of methotrexate-induced accelerated rheumatoid nodulosis: a follow-up study of 79 Caucasian patients with rheumatoid arthritis. Medicine (Baltimore) 80(4): 271278.

13. Cronstein BN, Naime D, Ostad E (1993) The antiinflammatory mechanism of methotrexate. Increased adenosine release at inflamed sites diminishes leukocyte accumulation in an in vivo model of inflammation. J Clin Invest 92(6): 2675-2682.
14. Cronstein B (2010) How does methotrexate suppress inflammation? Clin Exp Rheumatol 28:(5 Suppl. 61): S21-S23.

15. Palmer TM, Trevethick MA (2008) Suppression of inflammatory and immune responses by the $\mathrm{A}(2 \mathrm{~A})$ adenosine receptor: An introduction. Br J Pharmacol 153(Suppl. 1): S27-S34.

16. Yamamoto T (2013) Cutaneous necrobiotic conditions associated with rheumatoid arthritis: Important extra-articular involvement. Mod Rheumatol 23(4): 617-622.

17. Houlder EL, Millier MJ, Highton J, Gwynne-jones D, Stamp LK, et al. (2017) Expression of the genes facilitating methotrexate action within subcutaneous rheumatoid nodules. Clin Exp Rheumatol 35(6): 943-947.

18. Shimoura N, Fukunaga A, Nagai H, Oka M, Nishigori C (2015) EpsteinBarr virus-associated methotrexate-induced accelerated rheumatoid nodulosis. Acta Derm Venereol 95(1): 100-101.

19. Mackley CL, Ostrov BE, Ioffreda MD (2004) Accelerated cutaneous nodulosis during infliximab therapy in a patient with rheumatoid arthritis. J Clin Rheumatol 10(6): 336-338.

20. Cunnane G, Warnock M, Fye KH, Daikh D (2002) Accelerated nodulosis and vasculitis following etanercept therapy for rheumatoid arthritis. Arthritis Rheum 47: 445-449.

21. Kekow J, Welte T, Kellner U, Pap T (2002) Development of rheumatoid nodules during anti-tumor necrosis factor alpha therapy with etanercept. Arthritis Rheum 46(3): 843-844.

22. Kerstens PJSM, Boerbooms AMT, Jeurissen MEC, Fast JH, Assmann KJM, et al. (1992) Accelerated nodulosis during low dose methotrexate therapy for rheumatoid arthritis:an analysis of ten cases. J Rheumatol 19(6): 867-871

23. Kaye BR, Kaye RL, Bobrove A (1984) Rheumatoid nodules. Review of the spectrum of associated conditions and proposal of a new classification, with a report of four seronegative cases. Am J Med 76: 279-292.

24. Jeurissen MEC, Boerbooms AMT, van de PutteLBA (1989) Eruption of nodulosis and vasculitis during metho-trexate therapy for rheumatoid arthritis. Clin Rheumatol 8(3): 417-419.

25. Das SK, Kumar A (1995) Nodulosis during methotrexate therapy for rheumatoid arthritis. J Assoc Physicians India 43: 651.

26. Dash S, Seibold JR, Tifu ML (1999) Successful treatment of methotrexateinduced nodulosis with D-penicillamine. J Rheumatol 26: 1396-1399.

27. Berris B, Houpt JB, Tenenbaum J (1995) Accelerated nodulosis in a patient with psoriasis and arthritis during treatment with methotrexate. J Rheumatol 22: 2359-2360.

28. Garcia-Patos V (2007) Rheumatoid nodule. Semin Cutan Med Surg 26: 100-107.

29. Patatanian E, Thompson DF (2002) A review of methotrexate-induced accelerated nodulosis. Pharmacotherapy 22: 1157-1162.

30. Tilstra JS, Lienesch DW (2015) Rheumatoid Nodules. Dermatol Clin 33(3): 361-371.

31. Falcini F, Taccetti G, Ermini M, Trapani S, Calzolari A, et al. (1997) Methotrexate-associated appearance and rapid progression of rheumatoid nodules in systemic-onset juvenile rheumatoid arthritis. Arthritis Rheum 40: 175-178.

32. Combe B, Guttierrez M, Juan-Manuel A, Sany J (1993) Possible efficacy of hydroxychloroquine on accelerated nodulosis during methotrexate therapy for rheumatoid arthritis. J Rheumatol 20: 755-756.

33. Abraham Z, Rozenbaum M, Rosner I (1999) Colchicine therapy for lowdose methotrexate-induced accelerated nodulosis in a rheumatoid arthritis patient. J Dermatol 26: 691-694.

34. Williams FM, Cohen PR, Arnett FC (1998) Accelerated cutaneous nodulosis during methotrexate therapy in a patient with rheumatoid arthritis. J Am Acad Dermatol 39: 359-362.

35. Chatham WW (1992) Methotrexate-associated rheumatoid nodulosis: improvement with addition of sulfasalazine. Arthritis Rheum 35(suppl): S148. 
ISSN: $2574-1241$

DOI: 10.26717/BJSTR.2020.27.004470

Pankaj Bansal. Biomed J Sci \& Tech Res

(C) (P) This work is licensed under Creative

Submission Link: https://biomedres.us/submit-manuscript.php

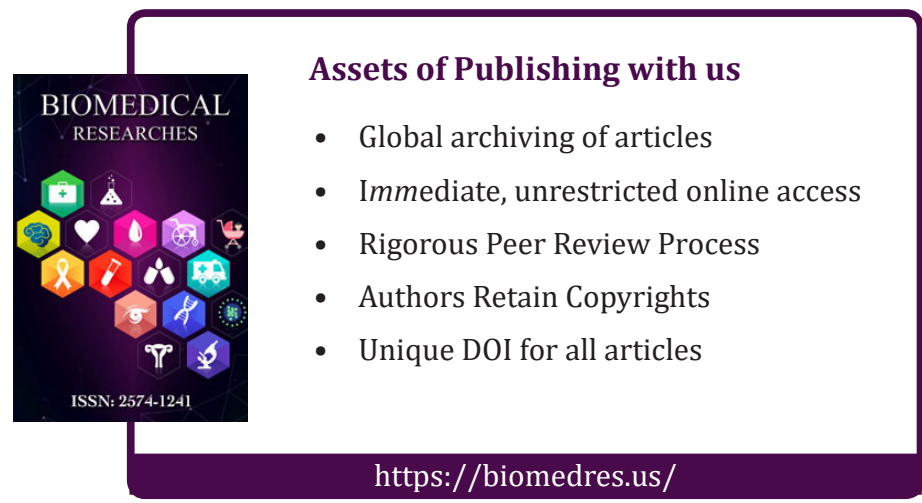

